\title{
For Debate - Trade Law and Alcohol Regulation: What Role for a Global Alcohol Marketing Code?
}

Andrew D. Mitchell, Professor, Melbourne Law School; Director, Global Economic Law

Network; Barrister and Solicitor of the Supreme Court of Victoria and the High Court of Australia.

Melbourne Law School, The University of Melbourne Victoria 3010 Australia

Jessica Casben, Research Fellow, Melbourne Law School, The University of Melbourne, Victoria 3010 Australia

Corresponding author: jessica.casben@unimelb.edu.au,jessica.casben@gmail.com

Submitted 28 May 16, initial review completed 28 June 16, accepted 7 Sept 16

Running Head Trade Law and an Alcohol Marketing Code

Word Count 3,490

\section{Conflict of Interest Declaration None}

Key words: alcohol, marketing, international trade law, international health agreement, World Trade Organization, WTO, tobacco, alcohol marketing code, litigation, dispute settlement

\begin{abstract}
Background and aims: Following calls for restrictions and bans on alcohol advertising, and in light of the tobacco industry's challenge to Australia's tobacco plain packaging measure, a tobacco control measure finding support in the WHO Framework Convention on Tobacco Control, this paper considers what role, if any, an international alcohol marketing code might have in preventing or reducing the risk of challenges to domestic alcohol marketing restrictions under trade rules.
\end{abstract}

Methods: Narrative review of international trade and health instruments and international trade court judgements regarding alcohol products and marketing restrictions.

Findings: The experience of European trade courts in the litigation of similar measures, suggests that World Trade Organisation rules have sufficient flexibility to support the implementation of alcohol marketing restrictions. However, the experience also highlights the possibility that public health measures have disproportionate and unjustifiable trade effects

This is the author manuscript accepted for publication and has undergone full peer review but has not been through the copyediting, typesetting, pagination and proofreading process, which may lead to differences between this version and the Version of Record. Please cite this article as doi: $10.1111 /$ add.13606

This article is protected by copyright. All rights reserved. 
and that the ability of a public health measure to withstand a challenge under trade rules will turn on its particular design and implementation.

Conclusion: International public health instruments are not immune to trade law challenges. Close collaboration between health policy makers, trade officials and lawyers, from as early as the research stage in the development of a measure to ensure a robust evidence base, will ensure the best chance of regulatory survival for an international marketing code. 


\section{Introduction}

The success of the WHO Framework Convention on Tobacco Control (FCTC) ${ }^{1}$ in securing widespread tobacco control activity in the developed and developing world ${ }^{2}$ has spurred consideration of the benefits of similar international instruments in other public health areas, particularly those aimed at addressing the "global epidemic" ${ }^{3}$ of non-communicable diseases. ${ }^{4}$ In light of the challenges brought against tobacco control measures under international trade agreements, ${ }^{5}$ it should be unsurprising that health policy makers are keen to ensure policy space for other preventative public health measures in the vast and ever expanding trade law environment. ${ }^{6}$ As noted by Landon et al. in this Supplement, a non-binding code of practice on alcohol control, potentially focused on alcohol marketing (Alcohol Marketing Code), is one such instrument being proposed. ${ }^{7}$

International health agreements are invaluable resources for policy makers seeking to develop public health measures and have "the capacity to significantly inform the way in which trade and investment treaties... are interpreted and applied". ${ }^{8}$ They do not, however, offer a panacea to the possibility of litigation of public health measures under international trade rules. ${ }^{9}$ Rather, as a review of European trade disputes regarding alcohol marketing restrictions suggests, ${ }^{10}$ the ability of a measure to withstand a dispute turns on the particular design and implementation of that measure. In this context, the strongest answer to a trade law challenge is a strong evidence base -for the regulatory intervention generally and for the specific design and operation of the particular measure/s being implemented. Such an aim will be best served by interdisciplinary collaboration between lawyers, experts and policy makers throughout the policy development process.

\section{Anticipating the form of an Alcohol Marketing Code}

In the context of public health instruments, a proposal for a non-binding code specifically refers to a non-binding "recommendation" adopted by the World Health Assembly pursuant to Article 23 of the Constitution of the World Health Organization (WHO Constitution). ${ }^{11}$ The International Code of Marketing of Breast-milk Substitutes (the Breast-milk Substitutes Code $)^{12}$ and the WHO Global Code of Practice on the International Recruitment of Health Personnel (the Health Personnel Code) ${ }^{13}$ offer examples of this kind of instrument. These non-binding codes are distinct from binding conventions adopted under Article 19 of the WHO Constitution, an example of which is the FCTC Framework Convention on Tobacco Control (FCTC). ${ }^{14}$ Provided the intention is to create a non-binding framework to regulate the marketing and advertising of alcohol products, one can presume it will take the form of a Code recommending action by WHO Member States.

\section{Recommendations under an Alcohol Marketing Code}


The scope and content of any Alcohol Marketing Code would necessarily be the subject of negotiations between the parties. However, the Breast-milk Substitutes Code and the FCTC, as instruments concerned with the marketing of consumer goods, and the WHO Global Strategy to Reduce the Harmful Use of Alcohol, ${ }^{15}$ which proposes policy options and interventions to target harmful alcohol use that include marketing restrictions, ${ }^{16}$ offer some guidance as to the kinds of measures that might be recommended.

Based on these materials it can be presumed that an Alcohol Marketing Code would likely capture promotion to the general public as well as point-of-sale advertising, and labels on or attached to a product ${ }^{17}$ and that its coverage might extend from traditional print and media advertising to event sponsorship, health warnings, internet promotion and product placement in film and television. ${ }^{18}$ To this end, recommendations might encourage the implementation of measures that: restrict advertising to young people in "family" television time slots and in youth-targeted publications such as teen magazines;; prohibit sponsorship by alcohol companies of public events; and restrict what advertising media are available to alcohol companies.

\section{Recommending substance over form}

Reflecting further on the Breast-milk Substitutes Code and the FCTC, it seems unlikely that an Alcohol Marketing Code would prescribe the particular form that a recommendation should take. Rather, it would recommend a style of regulation, and potentially key features of implementing measures, whilst leaving many of the details regarding the design and application of measures for state parties to determine, in accordance with their national laws and regulations. ${ }^{19}$

By way of example, Article 9.2 of the Breast-milk Substitutes Code recommends that infant formula be labelled with "a statement of the superiority of breastfeeding", among other things, in a "clear, conspicuous, and easily readable and understandable message...in an appropriate language". In implementing that recommendation regulators will need to exercise their own discretion as to where the placement of any labels should appear, the font size, colour and style, as well as the particular form of words to be used in conveying the recommended message.

Similarly, Article 11.1(b) of the FCTC requires Parties to adopt and implement "effective measures to ensure that [tobacco products] carry health warnings" that are "rotating", "large, clear, visible and legible", take up "no less than $30 \%$ of the principal display areas", and which "may be in the form of or include pictures". The particular content, design and placement of these warnings is, however, left to each implementing Party to determine. Even when read in conjunction with the Guidelines to Implementation, ${ }^{20}$ which provide considerably more detail on the various ways the obligation might be implemented, a Party ultimately has to make a number of regulatory choices in designing and applying an implementing measure. These regulatory choices can significantly influence how a measure 
will operate in practice, including how it will impact the relevant domestic market for trade in related goods and services.

\section{International trade rules}

The implementation of trade "related" measures is disciplined by international trade rules. Members of the World Trade Organization (WTO) agreements ${ }^{21}$ are obliged to implement domestic laws and regulations ("measures") in a WTO-consistent manner. This commitment is not limited to measures that regulate trade but also captures measures that relate to or impact trade. However, whilst international trade agreements might capture non-trade measures they do not prohibit trade effects.

Rather, trade rules are primarily concerned with disciplining discriminatory treatment and trade-restrictive regulation: that is, regulation that disadvantages imported products in favour of domestic products, or regulation that operates to restrict trade unnecessarily. Those of most relevance to marketing restrictions include: prohibitions on 'quantitative restrictions' (eg quotas) on imports; ${ }^{22}$ obligations of non-discrimination against or between imports; ${ }^{23}$ limits on the restrictions that can be placed on the supply of foreign services; and obligations of non-discrimination against or between foreign service suppliers. ${ }^{24}$ Specific rules also apply in respect of packaging and labelling requirements, ${ }^{25}$ and regarding the protection of the intellectual property of nationals of other WTO members. ${ }^{26}$

\section{Intersections between alcohol marketing restrictions and international trade law}

That the kind of measures that might be recommended in an Alcohol Marketing Code could impact trade in goods and services is uncontroversial. For example, restrictions that prohibit advertising to certain demographics, such as youth, impact on trade in alcohol products in so far as they result in a decline in consumption of those products. In another way, a measure that restricts alcohol advertising on television could be said to impact trade in advertising services as well as television broadcasting services. Legitimate, evidence based public health measures that apply to all products or services, regardless of their country of origin, should not fall foul of these requirements. Particular features of domestic markets can, however, mean that the impact of an otherwise even-handed measure is felt disproportionately amongst trading partners or as between domestic and foreign industry. For example, if domestic manufacturers of a product use component $X$ and foreign manufacturers of the same product use component $\mathrm{Y}$, regulation that prohibits the use of component $\mathrm{Y}$ only may be said to have a discriminatory impact.

In this way, the WTO Agreements apply to measures that regulate the marketing of alcohol products in the same way as they would apply to measures that regulate trade. The ultimate consequence of the trade law discipline is that if a WTO Member considers a particular alcohol marketing restriction to be in breach of WTO obligations it can challenge that measure under the WTO's dispute settlement system. ${ }^{27}$ A ruling of non-compliance by a 
WTO Panel or Appellate Body means a Member is obliged to remedy the non-compliance, for example through modification or repeal. ${ }^{28}$ An example of the WTO dispute settlement system being used to challenge a health measure's trade impacts can be seen in the, yet to be decided, dispute regarding Australia's introduction of tobacco plain packaging. ${ }^{29}$

\section{Public health exceptions}

In instances where a public health measure is challenged under trade rules, the analysis will turn first on whether the measure is found to restrict the provision of goods or services in a domestic market by foreign entities, or is designed or applied in a manner that discriminates between domestic and foreign goods or services. If the measure is found to breach WTO rules, the WTO agreements include inbuilt flexibilities that recognise that governments may have legitimate reasons to enact what might otherwise be WTO inconsistent measures to protect non-trade interests, such as public health. ${ }^{30}$ However, a determination of whether or not a measure can invoke a public health exception is not based simply on a declaration or designation of a measure as having a public health objective. Rather, the exceptions typically turn on whether the measure can be legitimately characterised as a public health measure (on an objective basis), ${ }^{31}$ whether the measure is "necessary" ${ }^{32}$ to protect human health, and whether the government has struck the right balance between the negative impact on trade and the health objective of the measure. ${ }^{33}$ These questions about the necessity and proportionality of a particular measure, both at law (de jure) and in practice (de facto), are critical to understanding the key issues facing public health policymakers in the trade law environment. ${ }^{34}$

In assessing the necessity and proportionality of challenged measures, WTO panels and the Appellate Body have applied a "weighing and balancing" approach of "putting all the variables of the equation together and evaluating them in relation to each other" determine the "extent to which the measure contributes to the realization of the end pursued" as well as "the extent to which the [measure] produces restrictive effects on international commerce". ${ }^{36}$ To this end, consideration is given to whether the measure at issue makes a contribution to its stated goal; ${ }^{37}$ whether that contribution justifies the resulting restriction on trade $;^{38}$ and whether there are any alternative measures that would satisfy the measure's objective with a less trade restrictive outcome. ${ }^{39}$ Because this analysis turns on the design and implementation of a particular measure, it cannot be said that the exception is available to all public health measures simply because they are public health measures. Rather, the question of whether the exception applies in a given circumstance is likely to be the subject of dispute settlement. Again, the current challenges to Australia's tobacco plain packaging requirements serve as an example of just such an instance. ${ }^{40}$

\section{The application of trade rules to alcohol marketing measures}


The application of international trade law rules to packaging and labelling measures has been the subject of considerable discussion to date. ${ }^{41}$ Whilst the need to consider the possible impacts of similar regulatory interventions in respect of alcohol and other unhealthy products is clear, this article does not seek to go over this well-trod ground, but instead is concerned with the intersections between trade rules and other non-labelling forms of alcohol marketing restrictions - such as sponsorship bans, restrictions on television or print advertising, or bans on the use of billboards for alcohol advertising. As such measures have not, to date, been the subject of WTO dispute settlement ${ }^{42}$ the implications are largely unknown.

European courts have, however, considered challenges to alcohol marketing restrictions in the context of the trade commitments made between members of the European Economic Community and European Union. Given the similarity of the relevant provisions in the WTO and European trade agreements 43 these cases may offer some insight into the ways in which alcohol marketing restrictions might be dealt with in the WTO, suggesting that public health exceptions will be available to justify alcohol advertising restrictions and cure trade effects that might otherwise be inconsistent with trade rules.

\section{The European Experience}

In 1991, the European Court of Justice held that a Catalonian ban on the advertising of beverages of over $23 \%$ alcohol content in mass media, on streets and highways, and in cinemas and public transport constituted a prohibited quantitative restriction but was proportionate to its public health goals. ${ }^{44}$ In 2004, the same court found that French legislation prohibiting the advertising of alcoholic beverages that resulted from television broadcasting of bi-national sporting events held in other Member States was in breach of market access commitments for services but was also proportionate to the public health objectives it sought to achieve. ${ }^{45}$ Furthermore, in 2009, the Norwegian Supreme Court, in applying an advisory opinion of the EFTA Court, ${ }^{46}$ held that a ban on the advertising of beverages of over $2.5 \%$ alcohol content, whilst constituting a prohibited quantitative restriction, was proportionate to the public health objectives sought. ${ }^{47}$ In each of these instances, the measure at issue was captured by the relevant public health exception and, thus, consistent with the implementing country's trade law commitments.

Successfully invoking an exception is not, however, assured. One case in particular demonstrates that the central issue in the application of public health exceptions is the impact of the particular measure on the relevant market. In 2003, the Swedish Market Court ${ }^{48}$ held that a ban on advertising of beverages containing more that $2.25 \%$ alcohol, which had been found by the EFTA Court to be a prohibitive quantitative restriction on imports, ${ }^{49}$ was not proportionate to the restrictions it imposed on trade. ${ }^{50}$ In reaching this decision, the Market Court held that the ban, in its current form, was ineffective in the pursuit of its public health objective. The Court reasoned that if the objective was, as was stated in the relevant policy, the protection of public health by reducing the harmful effects of alcohol consumption, the various exceptions that operated to permit alcohol advertising at the point of sale, via the 
internet, in editorial material, as well as through foreign newspapers and foreign TV channels, all of which were available in Sweden, undermined this objective to such an extent that the restriction on trade could not be justified. ${ }^{51}$

\section{The relationship between trade and health}

It would be easy to explain the Swedish Market Court's decision away as an example of trade rules undermining public health interests. In this context, much is often made of the difference between legally binding and non-binding international agreements, with the latter, the common status of public health instruments, being said to be easily "trumped" by binding trade law rules. ${ }^{52}$ However, this overshadows the central issue. The question is not whether an international health obligation, or recommendation, conflicts with trade rules but whether a particular health measure has been designed, implemented and applied in a manner that is consistent with trade rules. Recalling the level of discretion that exists for States in implementing their obligations under the FCTC or in giving effect to the recommendations of Breast-milk Substitutes Code, the answer to this question will undoubtedly lie in the detail as adopted and applied by a particular country with reference to the features of their market. It is not going to turn on the general features of a measure outlined in any Alcohol Marketing Code.

The Swedish Market Court's decision demonstrates this point. It highlights the fact that there can be legitimate questions to be asked about the trade impacts that result from the particular design and implementation of a public health measure. In this context, the Swedish response to the decision, which saw the implementation of a revised ban that prohibited radio and television advertising of alcohol, restricted the advertising of alcohol in periodical publications, other than point of sale materials, to beverages with an alcohol content of $15 \%$ of lower and required text warnings about the risks associated with alcohol consumption to appear alongside such advertisements, ${ }^{53}$ demonstrates that health measures can be calibrated in such a way that any resulting restrictions on trade are consistent with international trade rules. ${ }^{54}$ So to, do the previously discussed Catalonian, French and Norwegian measures.

\section{What role for an Alcohol Marketing Code}

By disciplining trade effects that are discriminatory or unjustifiably restrictive, as well as employing terms such as "legitimate" and "non-discriminatory" in connection with public health exceptions, international trade agreements provide considerable space for legitimate, effective and balanced public health measures while precluding those measures that, in fact, amount to disguised restrictions on trade or unjustified discrimination. It is here that the majority of the battle will be fought in trade disputes regarding public health measures-on questions of legitimacy, efficacy and balance. The key material for policy makers in defending a public health measure with respect to alcohol to any such challenge will therefore 
be evidence that supports the design and implementation of that particular measure in that particular market.

The existence of an Alcohol Marketing Code will not ensure that domestic restrictions on alcohol marketing and advertising are saved from lengthy and costly dispute settlement under international trade rules, nor provide certainty as to the outcome of any such disputes. This is centrally because an Alcohol Marketing Code will not provide evidence of the trade impacts of a particular measure, or negate the need for consideration of proportionality, and these questions will remain open to argument. Whether an Alcohol Marketing Code is binding or non-binding will not change these limitations. As can be seen from Australia's experience with tobacco plain packaging, the binding treaty that is the FCTC did not see a dispute avoided, nor its resolution prompt.

However, an Alcohol Marketing Code may provide evidence of widespread consensus as to: the legitimacy of the relevant health objective, the effectiveness of a measure in contributing to that objective, and the need different regulatory treatment as between some products or services. WTO dispute settlement bodies have shown a willingness to look to this kind of evidence from non-trade sources when considering disputed measures. ${ }^{55}$ Such evidence will likely be vital to any assessment of trade impacts and proportionality. The evidence base underpinning an Alcohol Marketing Code could also assist countries in building their own country-specific evidence justifying their pursuit of public health measures that have trade impacts. In this way, the Code could serve as a capacity building hub. For these reasons, the utility of a global consensus on alcohol control in the context of an international trade dispute should not be downplayed.

\section{Concluding remarks}

As this paper demonstrates, the alcohol industry's appetite for trade law litigation in response to alcohol marketing restrictions is clear. Whilst this has, to date, been limited to European trade rules and trading relationships similar issues have been raised in the WTO in respect of various Members' alcohol marketing restrictions. ${ }^{56}$ As measures restricting alcohol marketing become more widespread and prohibitive, the likelihood of legal challenges to the legitimacy and efficacy of alcohol marketing restrictions from the alcohol industry can be expected to increase. Replicating the strategy of the tobacco industry, the alcohol industry has already argued against proposed alcohol marketing restrictions by questioning theories underlying policy development ${ }^{57}$ and the voracity of evidence. ${ }^{58}$

Long term, expensive litigation, with the potential result of global regulatory chill, may in itself be a goal of tobacco and alcohol industries alike. An Alcohol Marketing Code can neither guarantee immunity under international trade law rules nor prevent the launching of a trade dispute; an international code should not be pursued for that reason alone. At the same time, the potential for international trade law challenges should not be used as justification for avoiding robust alcohol control measures. Rather, close collaboration between health policy 
makers, trade officials and lawyers, from as early as the research stage in the development of a measure, will ensure the best chance of regulatory survival. In particular, the early engagement of legal expertise can ensure an understanding of the issues likely to be the focus of a dispute. This, in turn, can inform the design of underlying research in support of a measure, the drafting of legislation that implements a measure, and the collection of evidence through monitoring and evaluating a measure, all of which can ensure a robust evidence base that gives a health measure the greatest chance of both avoiding and withstanding a challenge under trade rules. ${ }^{59}$

\section{Acknowledgements}

This article was produced with research funding from the Australian Research Council (Linkage Project scheme, project number LP120200028) pursuant to a grant to conduct independent research in conjunction with Cancer Council Victoria on the relationship between international trade and investment law and common risk factors for noncommunicable diseases. The authors thank the participants at Melbourne Law School's Global Economic Law Network Workshop Trade, Investment and NCDs - challenges for regulating alcohol and unhealthy foods for their invaluable comments. Particular thanks to Jonathan Liberman for his time and views. The views expressed in this chapter are the authors' own and are not necessarily shared by any government, employer or other entity. 


\title{
References
}

\author{
${ }^{1}$ WHO Framework Convention on Tobacco Control, opened for signature 21 May 2003, 2302 UNTS \\ 116 (entered into force 27 February 2005) (FCTC). \\ 2 Nikogosian H, 'WHO Framework Convention on Tobacco Control: a key milestone,' Bulletin \\ of the World Health Organization, 2010 Feb, 88(2): 83. doi: 10.2471/BLT.10.075895 \\ 3 World Health Organization, Global status report on non-communicable diseases 2010, \\ Geneva (2011) at vii. Available at: \\ http://apps.who.int/iris/bitstream/10665/44579/1/9789240686458 eng.pdf
}

$4 \quad$ See, for example, Hoffman SJ, Røttingen JA and Frenk J (2015). 'Assessing Proposals for New Global Health Treaties: An Analytic Framework', American Journal of Public Health, 2015 Aug, 105(8): 1523-1530; Taylor AL and Dhillon IS, 'An international legal strategy for alcohol control: not a framework convention—at least not yet', Addiction, 2013 Mar, 108(3):450-5, doi: 10.1111/j.13600443.2012.03919.x; and Room R, 'Healthy is as healthy does: where will a voluntary code get us on international alcohol control?', Addiction, 2013 Mar, 108(3):456-7, doi:10.1111/j.13600443.2012.03980.x.

$5 \quad$ Regarding Australia's tobacco plain packaging measures in the World Trade Organization: Australia-Certain Measures Concerning Trademarks, and Other Plain Packaging Requirements Applicable to Tobacco Products and Packaging (DS434) and Australia-Certain Measures Concerning Trademarks, Geographical Indications and Other Plain Packaging Requirements Applicable to Tobacco Products and Packaging (DS435, DS441, DS458 and DS467) (together, Australia-Plain Packaging); and regarding Norway's point of sale display bans in the European Free Trade Association States (EFTA) Court (and as applied by the Oslo District Court): Philip Morris Norway AS v The Norwegian State, Case E-16/10.

Challenges have also been brought against tobacco control measures under bilateral investment agreements, including in respect of Australia's tobacco plain packaging measures and Uruguay's graphic health warnings, however consideration of the international investment law framework is outside the scope of this paper.

$6 \quad$ For an outline of the options under consideration see Landon et al., 'International codes and agreements to restrict the promotion of harmful products can hold lessons for the control of alcohol marketing' [SUPPLEMENT]

$7 \quad$ Taylor AL and Dhillon IS, 'An international legal strategy for alcohol control: not a framework convention—at least not yet', Addiction, 2013 Mar, 108(3):450-5, doi: 10.1111/j.13600443.2012.03919.x; and, in response, Room R, 'Healthy is as healthy does: where will a voluntary code get us on international alcohol control?', Addiction, 2013 Mar, 108(3):456-7, doi:10.1111/j.13600443.2012.03980.x.

$8 \quad$ For discussion on the impacts of these international instruments in respect of public health policy development see Landon et al., (n8).

See also, Liberman J, 'Making Effective Use of Law in the Global Governance of NCD Prevention' in Voon T, Mitchell A and Liberman J (eds) Regulating tobacco, alcohol and unhealthy foods: the legal issues, Routledge (2014) at 24.

$9 \quad$ Baumberg B and Anderson P, 'Trade and health: how World Trade Organization (WTO) law affects alcohol and public health', Addiction, 2008 Sep, 103(2): 1952-8 at 1956, doi:10.1111/j.13600443.2008.02322.x.

$10 \quad$ For a consolidated summary of the measures considered see Baumberg B and Anderson P, 'Health, alcohol and EU law: understanding the impact of European single market law on alcohol policies', European Journal of Public Health, 18(4): 392-8 at 395, doi:10.1093/eurpub/ckn026. $11 \quad$ Constitution of the World Health Organization, adopted by the International Health Conference held in New York from 19 June to 22 July 1946, signed on 22 July 1946 by the representatives of 61 States (Official Records of the World Health Organization, 2, 100), and entered into force on 7 April 1948. 
12 World Health Organization, International Code of Marketing of Breast-milk Substitutes, Resolution WHA34.22 adopted by the 34 ${ }^{\text {th }}$ World Health Assembly, 21 May 1981.

$13 \quad$ World Health Organization, WHO Global Code of Practice on the International Recruitment of Health Personnel, Resolution WHA63.16 adopted by the 63rd World Health Assembly, 21 May 2010.

For discussion of the content of the Breast-milk Substitutes Code and the FCTC see Landon et al., (n8).

15 World Health Assembly, Global Strategy to Reduce the Harmful Use of Alcohol, WHA Res 63.13, 63rd sess, 8th plen mtg, WHO Doc WHA63/2010/REC/1 (21 May 2010).

16 For more detailed discussion of the Global Strategy, see Landon et al., (n8).

17 See, for example, Articles 5.3 and 9 of the Breast-milk Marketing Code respectively.

18 See, for example, FCTC Article 13(4) and related Guidelines for implementation of Article 13 of the WHO Framework Convention on Tobacco Control (Tobacco advertising, promotion and sponsorship). the FCTC.

See, for example, various instances of "in accordance with its national law", and similar, in

20 WHO Framework Convention on Tobacco Control, Guideline for implementation, World Health Organization (2013). Available at: http://apps.who.int/iris/bitstream/10665/80510/1/9789241505185_eng.pdf?ua=1

21 The WTO constitutes the central multilateral instrument in this area with 164 Members. International trade law commitments can also be found in an increasing number of bilateral and regional free trade agreements. These agreements often mirror the WTO commitments mentioned but secure higher commitments in other areas, such as tariffs and intellectual property protections; they might also provide alternative dispute settlement fora.

$22 \quad$ Marrakesh Agreement Establishing the World Trade Organization, opened for signature 15 April 1994, 1867 UNTS 3 (entered into force 1 January 1995), Annex 1A, General Agreement on Tariffs and Trade 1994 (GATT), Article XI.

23 Ibid., Articles I and III.

$24 \quad$ Marrakesh Agreement Establishing the World Trade Organization (n24), Annex 1B, General Agreement on Trade in Services (GATS).

25 Marrakesh Agreement Establishing the World Trade Organization (n24), Annex 1A, Agreement on Technical Barriers to Trade (TBT Agreement).

26 Marrakesh Agreement Establishing the World Trade Organization (n24), Annex 1C, Agreement on Trade Related Intellectual Property Rights (TRIPS Agreement).

$27 \quad$ While the WTO dispute settlement system hears disputes only between Member States it is not uncommon for industry to be closely engaged with the process, even to the extent of covering associated costs. For example, media reports suggest that media reports suggest that various tobacco companies are supporting WTO Members to bring claims against Australia's tobacco plain packaging measure in the WTO (n7).

See, Martin A, Philip Morris Leads Plain Packs Battle in Global Trade Arena, Bloomberg News (2013); available at http://www.bloomberg.com/news/2013-08-22/philip-morris-leads-plainpacks-battle-in-global-trade-arena.html

Damages are not awarded in the WTO dispute settlement system. However, where a respondent Member fails to implement an adverse ruling, the complainant Member may ultimately take retaliatory measures in the form of "suspension of concessions".

See, Marrakesh Agreement Establishing the World Trade Organization, opened for signature 15 April 1994, 1867 UNTS 3 (entered into force 1 January 1995), Annex 2, Understanding on Rules and Procedures Governing the Settlement of Disputes (DSU), Article 22:2.

$29 \quad$ Australia-Plain Packaging (n7).

30 These flexibilities can be by way of explicit exceptions, such as in GATT Article XX and GATS Article XIV, or be built into the substantive provisions, such as in the TBT Agreement Article 2.2. 
31 See, for example, GATT Article XX/ GATS Article XIV preamble which states that "measures are not [to be] applied in a manner which would constitute a ...disguised restriction on international trade".

32 See, for example, GATT Article XX(b)/ GATS Article XIV(b) which states that "nothing in this Agreement shall be construed to prevent the adoption or enforcement by any contracting party of measures...necessary to protect human, animal or plant life or health".

33 See, for example, GATT Article XX/ GATS Article XIV preamble which states that "measures are not [to be] applied in a manner which would constitute a means of arbitrary or unjustifiable discrimination between countries where the same conditions prevail".

$34 \quad$ For detailed discussion on how discrimination, market access and necessity analysis might apply to alcohol marketing restrictions see Gould, E, 'Trade Treaties and Alcohol Advertising Policy', Journal of Public Health Policy, 2005, 26(3): 359-376, doi:10.1057/palgrave.jphp.3200036.

For a detailed discussion on necessity and proportionality see, generally, Mitchell A D. Legal Principles in WTO Disputes, Cambridge University Press (2008) and McGrady B. Trade and Public Health: The WTO, Tobacco, Alcohol and Diet. Cambridge University Press (2011).

35 Appellate Body Report, Brazil-Measures Affecting Imports of Retreaded Tyres (BrazilRetreaded Tyres), WT/DS332/AB/R, 3 December 2007 at [182].

$36 \quad$ Appellate Body Report, Brazil-Retreaded Tyres (n37) at [145]-[147].

37 WTO panels and the Appellate Body accord WTO Members a degree of deference in determining what level of protection or regulatory objective they wish to achieve. For a detailed discussion on the limitations to this deference, see, Du M M. 'Autonomy in Setting Appropriate Level of Protection under the WTO Law: Rhetoric or Reality?'. Journal of International Economic Law 13, 2010, 1077.

$38 \quad$ Appellate Body Report, Korea-Measures Affecting Imports of Fresh, Chilled and Frozen Beef (Korea-Beef), WT/DS161/AB/R, WT/DS169/AB/R, 11 December 2000 at [161].

39 In this context, the importance of the objective the Member is pursuing is also taken into account. See, Appellate Body Report, EC-Measures Affecting Asbestos and Asbestos-containing Products, WT/DS135/AB/R, 12 March 2001 at [172]; and Appellate Body Report, Korea-Beef (n40) at $[162]$.

40 Australia-Plain Packaging (n7).

41 See, for example, O’Brien P, 'Australia's double standard on Thailand's alcohol warning labels.’ Drug Alcohol Rev (January 2013), 32, 5-10. DOI: 10.1111/j.1465-3362.2012.00485.x

Despite there being a number of disputes regarding measures that regulated trade in alcohol products, they related to the importation, sale and distribution of alcohol products, not the marketing of those products. See, Canada-Certain Measures Concerning Periodicals (DS31). Similarly, where challenges have been brought against measures that restricted the provision of services, including at least one directly considering advertising services, they did not involve restrictions analogous to those that would be contemplated under an Alcohol Marketing Code.

43 For example, in respect of trade in goods, prohibitions on quantitative restrictions feature in GATT Article XI, Article 30 of the Treaty Establishing the European Economic Community (EC Treaty) and Article 34 (ex Article 28) of the Treaty on European Union (EU Treaty).

Similarly, market access and non-discrimination commitments in respect of services are found in GATS Articles II, XVI and XVII and Article 56 (ex Article 49) of the EU Treaty.

GATT and GATS general exceptions provisions (GATT Article XX and GATS Article XIV) which provide for public health exceptions are also reflected in the EC Treaty (Article 36) and EU Treaty (Article 36, ex Article 30).

$44 \quad$ Aragonesa de Publicidad Exterior SA and Publivía SAE v Departamento de Sanidad y Seguridad Social de la Generalitat de Cataluña. Joined Cases C-1 and C-176/90 [1991] ECR I-4151. 45 Commission of the European Communities v French Republic. Case C-262/02 [2004] ECR I6569. 46 2005 .

Pedicel AS v Sosial-og helsedirektoratet. Case E-4/04, Judgment of the Court on 25 February 
$47 \quad$ Harbo, T. The Function of Proportionality Analysis in European Law. Hotei Publishing (2015) at 145-153. Citing Rt. 2009 s.839 (Pedicel Court of Appeal and Supreme Court judgments). 48 A specialist court that has jurisdiction to hear cases related to the Competition Act, the Marketing Act and other consumer and marketing legislation.

49 Konsumentombudsmannen v Gourmet International Products AB. Case C-405/98 [2001] ECR I-1795.

50 Marknadsdomstolens dom 2003:5 (Dnr B1/02), Konsumentombudsmannen v Gourmet International Products AB. 5.2.2003 (Swedish Market Court). Accessed, in Swedish, at: http://www.marknadsdomstolen.se/Filer/Avg\%C3\%B6randen/Dom03.05.pdf (informal translation). $51 \quad$ Marknadsdomstolens dom 2003:5 (Dnr B1/02), Konsumentombudsmannen v Gourmet International Products AB. 5.2.2003 (Swedish Appeal Court). Accessed, in Swedish, at: http://www.marknadsdomstolen.se/Filer/Avg\%C3\%B6randen/Dom03.05.pdf (informal translation). 52 See, for example, Friedman EF, Gostin LO, Buse K. 'Advancing the right to health through global organizations: the potential role of a Framework Convention on Global Health', Health Hum Rights 15: 71-86 (2013). See also, Gostin LO, Sridhar D, 'Global Health and the Law', 370 New Eng J Med 1732-1740 (2014). DOI: 10.1056/NEJMra1314094

53 Pursuant to 2005 amendments to the Alcohol Act. For detailed discussion see, National Foundation for Alcohol Prevention (STAP). 'Appendix: Regulations of Alcohol Marketing in 24 European countries' in Regulation of Alcohol Marketing in Europe (Utrecht, May 2007) at 188-192. Available at: http://ec.europa.eu/health/ph_projects/2004/action3/docs/2004_3_16_frep_a2b_en.pdf $54 \quad$ The amendments have not, to date, been challenged under European trade rules.

55 See, for example, the Panel's discussion of the FCTC and related Partial guidelines for implementation of Articles 9 and 10 of the WHO Framework Convention on Tobacco Control

Report of the Panel, United States-Measures Affecting the Production and Sale of Clove Cigarettes, WT/DS406/R, circulated 2 September 2011 at [7.413-415].

56 See, for example, World Trade Organization Committee on Technical Barriers to Trade, Specific Trade Concerns Raised in the TBT Committee, G/TBT/GEN/74/Rev.9, 17 October 2011. Available at: https://www.wto.org/english/news_e/news11_e/tbt_10nov11_e.htm

57 See, for example, the report commissioned by the Industry Association for Responsible Alcohol Use in response to proposed alcohol marketing restrictions in South Africa, which states: "There is no statistical relationship between per capita alcohol consumption and per capita advertising expenditure on alcoholic beverages. From this one can conclude that, if the adjustment for population growth is made in the data, the correlation decreases and the relationship is not statistically significant, i.e. there is no relationship between advertising expenditure and the consumption of alcohol."

Econometrix, Economic Impact of an Advertising Ban on Alcohol Beverages, March 2013 at 94. Available at: http://5737034557ef5b8c02c0e46513b98f90.cdn.ilink247.com/ClientFiles/econometrix/Econometrix/C ompany/Documents/Economic Impact of an_Ad_Ban_Econometrix.pdf

$58 \quad$ See, for example, Lion's submission to New Zealand's Forum considering possible further alcohol marketing restrictions, which states: "There is no compelling evidential basis that a ban or significant additional [advertising] restrictions will bring about a reduction in harm"

Lion, Lion submission to the Ministerial Forum on Alcohol Advertising and Sponsorship, April 2014 at 42 . Available at: https://www.health.govt.nz/system/files/documents/publications/group_submissions_folder_5.pdf $59 \quad$ Liberman J (n8) at 22. 


\section{University Library}

\section{- M M I E E R VA A gateway to Melbourne's research publications}

Minerva Access is the Institutional Repository of The University of Melbourne

Author/s:

Mitchell, AD;Casben, J

Title:

Trade law and alcohol regulation: what role for a global Alcohol Marketing Code?

Date:

2017-01-01

Citation:

Mitchell, A. D. \& Casben, J. (2017). Trade law and alcohol regulation: what role for a global Alcohol Marketing Code?. ADDICTION, 112, pp.109-116. https://doi.org/10.1111/ add.13606.

Persistent Link:

http://hdl.handle.net/11343/292210 